\title{
Participation and Development Buzzwords
}

\author{
Sajad Hussain \\ Institut d'Urbanisme et de Géographie Alpine (IUGA), Université Grenoble Alpes, \\ Grenoble, France \\ E-mail: sajadhussain1984@gmail.com
}

Received: April 16, 2020 Accepted: May 10, 2020 Published: May 13, 2020

doi:10.5296/ijgs.v4i1.17021 URL: https://doi.org/10.5296/ijgs.v4i1.17021

\begin{abstract}
The concept of sustainable development cannot be imagined without ownership, innovation, empowerment, and sustainability itself. In the same manner, it is not possible to achieve objectives of catchphrases like ownership, innovation, empowerment, and sustainability without ensuring genuine participation in the development projects. Genuine participation refers to a participatory process that takes place based on well-informed participants. A well-being outcome of participation relies on participants with sufficient knowledge of the issue and development process (Hussain, Khuhro, 2019). It is different from mobilisation campaign that emphasis on particular project objectives. In order to achieve goals of sustainable development, well-being participation is an essential step to take. This paper argues that a lack of real participation potentially restricts a sustainable development project to achieve objectives of ownership, innovation, empowerment, and sustainability, respectively.
\end{abstract}

Keywords: Participation, Innovation, Empowerment, Sustainability, Ownership

\section{Introduction}

Participation is considered as a key to community development (Kashi \& Ghobadi, 2013). Without introducing a well-being grassroots level involvement of people in a sustainable development project or program, it is not possible to ensure the notions of ownership, innovation, empowerment, and sustainability. However, the well-being outcome of the participatory process depends on the capability of knowledge of participants. Capacity building of participants ahead of involvement through awareness or external knowledge is an indispensable step to take in a development project - program or policy (Hussain \& Khuhro, 2019). Participation is neither a bottom-up approach as presumed and nor a top-down; instead, it has both features.

Participation is often misunderstood as an approach to build the capacity of communities. 
Although, cooperation requires the capable participants for well-being outcomes of a participatory process (Hussain \& Khuhro, 2019). Community development projects and programs widely use the Participatory Rural Appraisal (PRA) approach (Edward, 1997; Kurbanova, 2012) which heavily relies on indigenous or local knowledge on the cost of mutual knowledge sharing which is equally important. It is significant for development professionals before proposing and implementing a project to equip themselves with the local knowledge of targeted areas and based on that understanding build the capacity of participants to fill the knowledge gap before involving the community in a development project.

Human decisions are often driven by emotion which in psychological terms called "system one" and mentioned system is built upon the local knowledge that we acquire from surroundings including family, neighbourhood, culture, religion etc. While system two is used for making a rational decision and take much energy (Kahneman, 2011). Nonetheless, to make a well-being decision, a mind needs sufficient information that contrast or confirm the choice as well as being or not. Unless a person is provided with well-being knowledge which helps him/her to understand the dilemmas and reject or accept the proposed solution, the change is impracticable.

The term 'genuine participation' refers to the participatory process based on participants who can take part in the development process and make well-being decisions based on internal and acquired knowledge. The mobilisation that takes place after the project objectives are described cannot be taken into account to a well-being involvement of communities. The awareness campaigns are often designed to achieve project or program goals. Yet, genuine participation allows people to decide what is better for them and is critical to attaining ownership, innovation, empowerment, and sustainability in any development project or policy (Hussain \& Khuhro, 2019). The said form of participation requires educating and training people about current social, economical and environment issues and how people in various regions are tackling them with their local resources. Participation rigorously based on local or indigenous knowledge is not able to serve the purpose of participatory development. In the present knowledge gap between development organisations and communities to achieve ownership, innovation, empowerment, and sustainability nothing but a dream.

Ownership is consists of two major components, control on utilisation and outcomes (Ben-Ner, \& Derek, 2008) and to utilise and achieve well-being outcomes requires the capacity of knowledge to do so. Innovation requires participation with various knowledge background (Gourova \& Toteva, 2011), which means that without genuine participation, innovation cannot take place. Empowerment and participation depend on each other (Claridge, 2004) and empowerment requires capacity building to change the power-relation within a society. Lastly, advanced knowledge to make well-being decisions in terms of utilisation of resources is a prerequisite to attain the notion of sustainability (Hussain, Khuhro, 2019). It is essential to understand the core of this paper, which term 'Genuine Participation' before moving into details. It will help readers in understanding the paper.

\section{Genuine Participation}

In development theories and practice, participation has been a central point of discussion for 
practitioners as well as in academia. The buzzword (participation) of today's development discourse emerged in the late $1970 \mathrm{~s}$ as an alternative paradigm of the development interventions, and since the 1990s it is widely used (Zafarullah \& Huque, 2012). Participation has been taken in top consideration in all major and minor development projects and programs. Hardly any development area has escaped its influence. To incorporate the community involvement in development projects, significant approaches, such as Participatory Rural Appraisal (PRA), were introduced in the 1980s, which later evolved with time (Chambers, 1994). The principal objective of the approach is to involve people from assessment to the evaluation process of a development project.

According to WHO (2000), community participation is a process that allows people of a community to raise their voice and share their opinions and influence the decision making in favour of their well being. To alter or make a well-being decision requires sufficient knowledge of the process of development and issue. However, current participatory practices heavily rely on local or indigenous knowledge. The commonly used term 'Genuine Participation' refers to enhancing the understanding of participants on the process of participation, current issues and scientific thinking and decision-making process before involving them in the development process.

To investigate the link between genuine participation and buzzwords of development, including ownership, innovation, empowerment, and sustainability, it was imperative to identify an appropriate research design that can help in collecting and analysing the data on participation and its link with the above randomly chosen catchphrases.

\section{Research Design}

This research has utilised qualitative methodology to dig deeper into a problem and unearth a potential solution it requires a qualitative research method (Mason, 2002; Hancock, Okleford, $\&$ Windridge, 2009). The vast experience in participatory development projects and intensive analysis of available research on participation helped to identify the link between participation and the thematic areas of ownership, empowerment, innovation, and sustainability. Theoretical thematic coding is used to narrow down and analyse the relationship of participation with ownership, innovation, empowerment, and sustainability.

\section{Participation and Buzzwords}

Participation is directly proportional to valuable concepts of sustainable development, including ownership, innovation, empowerment, and sustainability. The absence of people's genuine involvement in development process, confines the well-being outcomes. In order to augment the participatory process, it is essential that participants are well equipped with updated knowledge. It will be naïve to consider the approach as complete This paper highlights the association of genuine participation with development 'buzzwords' including ownership, innovation, empowerment, and sustainability and also discusses the obstacles in accomplishing these goals in a participatory development project.

\section{Participation and Ownership}

Disallowing citizen's involvement is often condemned as the treachery of democratic 
tradition (Fagence, 1977). Evading people's participation in the development processes of an area or country leads to instability: often people do not own the project or the policy decisions and take a stand against it. Therefore, it is significant for any development project or policy that the targeted population owns a particular venture.

Ownership is a psychological state of mind in which a person feels possessive towards something. The sense of ownership, which is essential to sustainable development, is directly allied to genuine participation. According to Pierce, O'Driscoll, \& Coghlan (2004), understanding of work and control on utilisation gives a sense of ownership. Nevertheless, comprehension of work and power requires knowledge that comes via training or awareness. That drags attention towards current participatory practices that rely only on local knowledge whereas; to understand and achieve well-being result of the participatory development process requires an understanding of the process.

Marks and Davis (2012), in their study of Kenya's rural water system, mentioned that the involvement of people in projects from design to cost-sharing results in greater ownership. Nevertheless, greater involvement requires sufficient knowledge of the issue (Hussain and Khuhro, 2019) and farmers possess adequate know-how of the water system. Therefore, it is hypothesised that already ample understanding of the water system increased the participation and sense of ownership.

The above example shows how participation leads to ownership which is essential for sustainable development and also reflects the importance of capability of knowledge in engagement. Participation enhances the ownership and to enhance ownership; it is essential to increase participants' understanding of issues and solutions by providing them with necessary external knowledge. A combination of internal and external knowledge leads a development project to innovation.

\section{Participation and Innovation}

Innovation is another buzzword in development discourse. According to Brown (2010), innovation is conceptually vague; it has a broad sense that can be taken into many directions. The common understanding of innovation is technological development. In social terms, innovation refers to any technological development that helps improve well being in society. Pollitt and Hupe (2011) called innovation as a 'magic word' which can solve old dilemmas. Innovation provides a new solution to problems not even in technological but in the social arena as well.

According to the Organisation for Economic Co-operation and Development (OECD), (2012), innovation plays a crucial role in addressing the urgent development challenges such as poverty. Innovation is imperative for all phases of development (OECD, 2012), and innovation comes with people's participation (Gourova \& Toteva, 2011). Community involvement in planning and policy not only improves the quality but also builds the community as a resource for decision making (Kathryn, Quick, and Feldman, 2011). Community involvement in projects often brings innovative ideas to solve the problems.

A survey was conducted in 2008 from 303 European firms about how internal and external knowledge contributes to innovation. The survey result showed that inhouse learning or in other words, internal knowledge alone is not sufficient for innovation (Svetina \&Prodan, 
2008). Local or indigenous knowledge led participatory processes cannot contribute to achieving innovation in development projects. Innovation requires participants with local and external knowledge which ultimately means without genuine participation objective of innovation cannot be achieved, and innovation is the backbone of the sustainability of a development project.

\section{Participation and Sustainability}

World Commission on Environment and Development (WECD) provided one of the foremost definitions of sustainable development in 1984. According to WCED, "development that meets the needs of the present without compromising the ability of future generations to meet their own needs" (WECD, 1987, p. 43). The definition refers to the consideration of environmental, social, and economic development in order to use resources efficiently. Nonetheless, to incorporate environmental, social and economic issues, intensive training is a prerequisite. That ultimately means with the current participatory approach, which relies on local knowledge, it is not possible to achieve sustainability.

People with local knowledge can consider social, environmental and economic issues in their decision making without having sufficient knowledge or training. The top 20 reported reasons on the basis British people voted in favour of leaving the European Union were about the sustainable policies of the European Union, such as a ban on high energy consuming items and limited fishing (The Telegraph, 2016). According to Hussain, 2016, in the flood emergency response 2010, in the Sindh region during a focus group, discussion women preferred pieces of cloths over menstrual pads and ruby cups because they were not aware of such sustainable and comfortable products. A person cannot choose something he is not aware of, and awareness comes with external knowledge. External knowledge plays a vital role in the decision-making process (Kahneman, 2011), and it comes with training, education, and exposure.

Participation is vital for sustainability, but for well-being outcomes, genuine participation is manifest. Awareness regarding issues before participation is an essential step towards ensuring sustainability. Without knowing the facts that sustainable policies are actually in favour of our coming generations, it would not be possible to convince people to sacrifice their current luxuries. Capacity building before participation ensures sustainability, and it also empowers people.

\section{Participation and Empowerment}

Empowerment often takes place as a mainstream scheme for nongovernmental organisations in their projects and programs for development. Gender equality, empowerment, and bottom-up participation are the key to sustainable and equitable development processes (Lewis \& Kanji, 2009). The ideology of empowerment plays a significant role in shifting power relations within the communities and state.

According to Cornwall and Brock (2005), "empowerment" is a buzzword of development discourse. Empowerment is a social process to change the power relationship among excluded groups by building their capacity and mobilising them for collective action for their rights (Fals \& Rahman, 1991). Participation and empowerment are in 'chain of equivalences' 
when two words come to a chain of equivalence; their meaning resides in connection with them (Cornwall and Brock, 2005). Yet, in development discourse, empowerment is often considered as a product of participation.

In the case of participation and empowerment, both the notions are dependent on one another. Participation allows people to take part in the decision-making process and builds the capacity of the people to decide on the issues concerns with them. On the other hand, to empower people to not only participate but make well-being decisions in their favour; the capacity building is an essential step to take.

It is essential to build the capacity of people and train them in order to change power-relation (Hussain, 2016). Without meaningful participation, empowerment can remain an empty, unfulfilled promise (Cornwall and Brock, 2005). Term "meaningful" participation, refers to active participation, which means not only physical appearance or passive participation but consideration of ideas/voices is also essential in the decision-making process. Additionally, without having sufficient knowledge of process and issues, people do not involve in decision making, and if one does his/her opinion will not be incorporated in the decision.

\section{Conclusion}

History provides evidence that cooperation has foremost contribution behind achievements of human beings (Harari, 2016) and this cooperation needs enrichment between poverty-stricken communities and development agencies. A sustainable development project, program or policy cannot be imagined without the concept of innovation, sustainability, ownership, and empowerment and all these notions cannot be achieved without participation. Nonetheless, participation is often misguided with the impression of bottom-up notion, although participation works in both ways bottom-up and top-down. Participation means that all stakeholders participate equally. Development professionals participate by learning communities and assisting communities to learn and updated knowledge that can ease their lives and helps them to understand issues and find out well-being local solutions.

To sum up, participation with the capability of knowledge is essential to achieve well-being outcomes of development projects, programs, and policies. To achieve the valuable component of sustainable development including ownership, innovation, sustainability, and empowerment; participation with awareness is necessary. We cannot expect communities to have an understanding and response current environmental, social and economic issues based on their limited local indigenous knowledge. May be to receive the aid people from under-privileged communities participate in development projects. Still, those development projects will not change the situation of poor communities in the long term.

\section{Acknowledgement}

I would like to acknowledge the technical support of Mrs Agnieszka Kucab in completion of this paper. I also would like to thank my professors and mentors Kirsten Koop, Naureen Amin and M. Qasim Nizamani for their guidance.

\section{Reference}

Ben-Ner, A., \& Derek, J. (2008). Employee Participation, Ownership, and Productivity: A Theoretical Framework. Industrial Relations: A Journal of Economy and Society, 34, 532-554. 
https://doi.org/10.1111/j.1468-232X.1995.tb00387.x

Brown, L. (2010). Balancing Risk and Innovation to Improve Social Work Practice. British Journal of Social Work, 40(4), 1211-1228. https://doi.org/10.1093/bjsw/bcq013

Claridge, T. (2004). Designing Social Capital Sensitive Participation Methodologies. The report, Social Capital Research, Brisbane, Australia.

Cornwall, A., \& Brock, K. (2005). Beyond Buzzwords, "Poverty Reduction", "Participation" and "Empowerment" in Development Policy. United Nations Research Institute for Social Development. Overarching Concerns Programme.

Edwards, M. (1997). Using PRA in organisational self-assessment. PLA Notes, 29, 10-14.

Fagence, M. (1977). Citizen Participation in Planning (1st ed.). Oxford. New York. Pergamon Press. https://doi.org/10.1016/B978-0-08-020398-0.50013-9

Gourova, E., \& Toteva, K. (2011). Raising Creativity and Participation in Innovation and Knowledge Management Activities' Conference: 17th International Conference on Concurrent Enterprising 2011. Aachen, Germany.

Hancock, B., Windridge, K., \& Ockleford, E. (2007). An Introduction to Qualitative Research. The NIHR RDS for the East Midlands / Yorkshire \& the Humber.

Harari. (2017). Homo Deus: A Brief History of Tomorrow (1st ed.). New York. Harper. https://doi.org/10.17104/9783406704024-1

Hussain, S., \& Khuhro, R. (2019). Eleven-Barriers to Participation and One-Root. Journal of Sustainable Development, 12(3), 1913-9063. https://doi.org/10.5539/jsd.v12n3p1

Hussain, S. (2016). Participation and Knowledge- A missing link. Master Thesis. University Grenoble. France.

Kahneman, D. (2011). Thinking, fast and slow. New York: Farrar, Straus and Giroux.

Kashi, S. S., \& Ghobadi, J. G. (2013). The Role of Citizen Participation in the Sustainable Development of Urban Areas: case study Qaemshahr city. International Research Journal of Applied and Basic Sciences, 6(7), 910-916.

Kathryn, S. Q., \& Martha, S. F. (2011). Distinguishing Participation and Inclusion. Journal of Planning Education and Research, 31(3) 272-290. https://doi.org/10.1177/0739456X1 1410979

Kurbanova, B. (2012). Constraint and Barriers to Better Land: Stewardship: Analysis of PRA in Tajikistan. Squires, Victor R. (Ed.). (2012). Rangeland Stewardship in Central Asia: Balancing Improved Livelihoods, Biodiversity Conversation and Land Protection. (pp. 129-158). London. Springer. https://doi.org/10.1007/978-94-007-5367-9_7

Lewis, D., \& Kanji, N. (2009). Non - Governmental Organisations and Development. New York, Routledge Taylor Francis Ltd. 


\section{Macrothink}

International Journal of Global Sustainability

ISSN 1937-7924 2020, Vol. 4, No. 1

Marks, S. J., \& Davis, J. (2012). Does User Participation Lead to Sense of Ownership for Rural Water Systems? Evidence from Kenya. World Development, 40(8), 1569-1576. https://doi.org/10.1016/j.worlddev.2012.03.011

Mason, J. (2018). Qualitative Researching. (2nd ed.). London: Sage.

Organisation for Economic Co-operation and Development (OECD). (2012). Innovation for Development, A discussion of issues and overview of the work of the OECD Director of science, technology, and industry.

Orlando, F. B., \& Rahman, M. A. (1991). Action and Knowledge: Breaking the Monopoly with Participatory Action Research. Intermediate Technology Publications, London.

Pierce, J. L., O'Driscoll, M. P., \& Coghlan, A.-M. (2004). Work environment structure and psychological ownership: The mediating effects of control. The Journal of Social Psychology, 144(5), 507-534. https://doi.org/10.3200/SOCP.144.5.507-534

Pollitt, C., \& Hupe, P. (2011). Talking about Government: The Role of Magic Concepts. Public Management Review, 13, 641-658. https://doi.org/10.1080/14719037.2010.532963

Robert, C. (1994). The Origins and Practices of Participatory Rural Appraisal. World Development, 22(7), 953-969. https://doi.org/10.1016/0305-750X(94)90141-4

Svetina, A. C., \& Prodan, I. (2008). How Internal and External Sources of Knowledge Contribute to Firms' Innovation Performance. Managing Global Transitions, 6(3), 277-299.

The Telegraph, 22nd June 2016, 20 Reason you should vote to leave the European Union. Retrieved July 71, 2016 from http://www.telegraph.co.uk/news/2016/06/22/20-reasons-youshould-vote -to-leave-the-european-union/

World Commission on Environment and Development (WECD). (1987). Our Common Future. Oxford University Press.

Zafarullah, H., \& Huque, A. S. (2012). Managing Development in a Globalised World: Concepts, Processes, Institutions. New York. Routledge.

\section{Copyright Disclaimer}

Copyright for this article is retained by the author(s), with first publication rights granted to the journal.

This is an open-access article distributed under the terms and conditions of the Creative Commons Attribution license (http://creativecommons.org/licenses/by/4.0/). 